\title{
Relocations of Sports Spectators' Customer Experiences
}

\section{A sporteseményt nézők vásárlói élményeinek áthelyeződése}

\author{
Ekaterina Glebova ${ }^{1,2}$, Michel Desbordes ${ }^{1,2}$, Gabor Geczi $^{3}$ \\ 1 Université Paris-Saclay CIAMS, 91405, Orsay, France \\ 2 Université d'Orléans, CIAMS, 45067, Orléans, France \\ 3 University of Physical Education, Department of Sports Management, Budapest, Hungary
}

\begin{abstract}
In this paper, we aim to explain a phenomenon of 'Sports Spectators' Customers' Experiences' (SSCX) locations", overview today locations of sports consumption experiences for sports fans, find the changes in these locations, and define the main drivers of shift. It provides a concept for studying the effects of new technologies on sports spectator experiences, with the intention of future research at the intersection of topics Customer Experience (CX), Sports Spectacle (SS), and Technology. The main novelties of this study imply a rapid technology uptake and appear of absolutely new ways of sports spectating and locations. The culture of sports consumption and fans' habits are the subject of changes, accordingly, it impacts SSCX. This study draws on pieces of literature spanning from technology, Sport Spectacle, Stadia, CX, Optimization strategy and combines them with data collection and analysis in the spirit of grounded theory. Data was collected in semi-structured interviews $(\mathrm{N}=10)$ with professional sports managers or technologies specialists. The outcome is a new conceptual framework on Locations and Relocations of SSCX. This question is important in the framework of the study of technological impact on SSCX. It helps Sports Managers and Marketing Professionals to better understand the research target audience, outline technological trends, find links and interrelation and define their impact.
\end{abstract}

Keywords: Sports Spectacle, Customer Experience, Mediatory watching, Technology, Content Access, Digital Transformation, Sports Media, Social Media

Összefoglaló - Ebben a cikkben arra törekszünk, hogy elmagyarázzuk a sportrajongók vásárlói tapasztalatainak (SSCX) helyszíni jelenségét, átnézzük a sportfogyasztási tapasztalatok mai helyét a sportrajongók számára, megtaláljuk a változásokat ezeken a helyeken, és meghatározzuk a változás fó mozgatórugóit. Koncepciót javaslunk az új technológiák sportnézói tapasztalatokra gyakorolt hatásainak tanulmányozására, azzal a céllal, hogy a jövőbeni kutatásokat az ügyfélélmény (CX), a sportlátvány (SS) és a technológia metszéspontjában megtalálható legyen. A tanulmány fó új szempontjai feltúnnek a sport látványának teljesen új módjai és helyszínei és a technológia gyors elterjedését vonják maguk után. A sportfogyasztás kultúrája és a szurkolók szokásai változások tárgyát képezik, ennek megfelelóen hatással van az SSCX-re. Ez a tanulmány a technológia, a Sport Spectacle, a Stadia, a CX, az Optimalizálás stratégiáján átívelő szakirodalomra támaszkodik, és ezeket az alapos elmélet szellemében ötvözi az adatok gyújtésével és elemzésével. Az adatokat félig strukturált interjúkban $(N=10)$ gyújtöttük szakmai sportmenedzserekkel vagy technológiai szakemberekkel. Az eredmény egy új fogalmi keretrendszer az SSCX helyeiról és áthelyezéséről. Ez a kérdés fontos az SSCX-re gyakorolt technológiai hatás tanulmányozása keretében. Segít a sportmenedzsereknek és a marketing szakembereknek a kutatás célközönségének jobb megértésében, a technológiai trendek felvázolásában, a kapcsolatok és az összefüggések megtalálásában és azok hatásának meghatározásában.

Kulcsszavak: sportlátvány, vásárlói élmény, mediátor figyelés, technológia, tartalomhoz való hozzáférés, digitális átalakítás, sportmédia, közösségi médiai 


\section{Introduction}

Sports spectatorship is one of the favorite pastimes (Phua Joe, 2010; Teodorakies, 2014). Besides attending live events, sports fans may choose a variety of options of mediatory sports watching including fan zones, broadcasts, podcasts, and mobile apps to keep up with sports news, teams, athletes, events, organizations, brands. Broadcast media including television and radio enable fans to watch or listen to "live" events when they are not able to attend them in person. Nowadays the wide dissemination of smartphones, tablets, Internet access, Mobile apps, Immersive Technologies (ImT, XR) provides an opportunity for a 24/7 sports fan experience, 24/7, any time, from anywhere.

Today, major television networks telecast sporting events in their lineup, and on cable, there is an even greater wealth of sports programming on various channels. Additionally, the vast number of televised sports played at the professional and other levels, and the choices for sports fans become virtually endless.

New technologies open new opportunities for ways to deliver SSCX, accordingly it reshape forms of CX along with places of such experience. But changes are fast and should be researched accordingly.

This paper aims to investigate different locations of Sports Spectating Customer Experiences (SSCX) in nowadays sports fandom environment through overview, typology, and synthesis of data.

\section{Theoretical background}

Nowadays, in times of digital transformation of all industries on all levels, it seems especially feasible to understand processes in society and particular fields. Sports Spectacle has been affected by rapid development and diffusion of technologies in many terms, consequently, delivering "smooth", personalized, immersive, and cutting-edge experiences is the present and future of industry and technology is the main driver of improving SSCX (Glebova \& Desfontaine, 2020). Important to add, that defining and improving customer experience is a growing priority for market research because experience has replaced quality as the competitive battleground for marketing (Klaus \& Maklan, 2012), and the concept of CX in the sports marketing field has been widely disclosed (Chavanat
\& Bodet; 2014, Theodorakis, 2014; Biscaia, 2015; Huetermann, 2019).

Nikolai (2020) uses the term "dispersed fan" to "describe the geographically distant populations of the global sports fan community" (distant fan, satellite fan, displaced fan), telling about internationalized and digitalized global sports fan community. As the result of digital transformation on a global scale, sports fan classifications are emerging $(\mathrm{Pu}$ \& James, 2017; Glebova \& Desfontaine, 2020). Also, Nikolai (2020) mentions a kind of sports consumer who is following a "geographically distant sports league, team or athlete via the internet, social media, or television". Then he concludes that the literature of sports consumer typologies is already including the three additional fan types distant fan, satellite fan, and displaced fan, which along with the local fan form the global sports fan community.

At the same time, Glebova et al. (2020), describing the changes in modern stadia SSCX, outline the key areas of sports venues transformation: multipurpose nature of facilities, modular infrastructure, seating, HVAC, Access, safety and smart ticketing, social media, mobile and immersive experiences, restoration and collaborations, outsourcing, stadium connectivity. It was emphasized that one of the main drivers of the stadia revolution is the work on delivering the next level of stadia SSCX, attracting fans out from their mediatory watching and bringing them right back to a stadium. This can be seen as an example of a shift from physical to virtual locations of spectating, and back, combining different sources, tools, and modes of sports content consumption (switching between the online, offline, home, stadium, "mobile").

A few empirical studies let us understand that the real physical location of a sports fan and his consumer preferences "location" may be scattered. For example, Behrens and Ulrich (2020) have indicated that prototypical fan behavior of satellite fans results in more positive attitudes towards them among local fans. Moreover, the effects of "prototypicality" decrease the more the local fans perceive the internationalization of team sports to be a process that deprives them of social and economic resources.

Collin et al. (2014) have disclosed the term "displaced fan", focusing attention on individuals who 
move away from their hometowns often remain fans of their hometown teams, examining the impact of new media, differences between hometown and current community identification, and the impact of proximity to a National Football League (NFL) market on the team identification of displaced fans. They demonstrated that social media, Internet streaming, and hometown identification affected hometown team identification.

\section{Methodology / Approach / Design}

This study draws on literature spanning from technology, Sport Spectacle, Stadia, CX and combines them with data collection and analysis in the spirit of grounded theory: qualitative data generation was used in this grounded theory study to sets out to construct theory from data, systematically obtained and analyzed using comparative and iterative analysis.

Semi-structured interviews $(\mathrm{N}=10)$ with international sport marketing professionals have been conducted in order to answer the research questions:

1. What are "physical" and "virtual" locations for sports consumption?

2. Where are physically located the places of sports spectating consumption?

3. What are ways to consume sports distantly?

4. How to define primary, secondary, partially, fragmentally situated locations of CX?

5. What factors and trends may affect SSCX relocation?

The qualitative approach lets us better understand the current transformation of SSCX and the reasons for these processes, outlining the main drivers of change and "relocations", we use verbatim to deliver dataset pieces without rephrasing and modifications, following the logic of the current paper.

\section{Discussion}

\section{Locations of SSCX: physical and virtual}

Nowadays the wide dissemination of smartphones, tablets, Internet access, Mobile apps, Immersive Technologies $(\operatorname{ImT})$ provides an opportunity for a $24 / 7$ sports fan experience. However, According to "Performance communications" report, it's less than $7 \%$ almost entirely watched live, accordingly, fans aren't "time-shifting", they're "place-shifting" (Wann et al., 2019): "The recent days main changed brought by broadcasting: Amazon broadcasting British Premier league, UEFA TV with many highlights. People start to get used to using these solutions. We will see more and more people enjoying amazing quality broadcasts at home, probably inviting friends. At the same time, many fans will be watching everywhere on apps and mobile platforms" (Andrei Angelescu).

"Of course, the sports fans' experiences have relocated in the last years. Why? Because society is evolving, there are new hi-tech devices launched almost every month. Right now, the supporters, the fans, are gaining their experiences both at home and at the 'arena' (stadium). Some clubs have well-known 'fan zone' areas where people can interact, can create a bond between them and, at the same time, they become a part of that club's family. The feeling of belonging. This is a story for like 2 or 3 hours before the game. During the game is all about passion. And in the end, the referee whistles the end of the game, and they are all going home. And from now on it's all about the digital, the day by day technology. The channels where the fans can be connected with the club's life every single day. This is something that most of the clubs are missing. And it doesn't seem to get better" (Ciprian Enache).

The location of the Sport spectator CX can be defined by the way the sports content is accessed. In today's digital world, it seems appropriate to distinguish "virtual" locations and "physical" locations of sports experiences. Physically being in one place, viewers can be mentally located in a completely different place in the real or virtual world. Accordingly, in terms of content consumption, the "physical location" of the fan does not matter, however his "virtual location" is crucial.

Physical location means the geographical place(s) where a spectator is situated during the process of spectating experience. Virtual location means the way of accessing sports content.

Infographic 1 . outlines physical and virtual locations of SSCX, hence, let structure and synthesize actual locations of SSCX (table 1.). 


\section{Accessing Sports \\ Content}

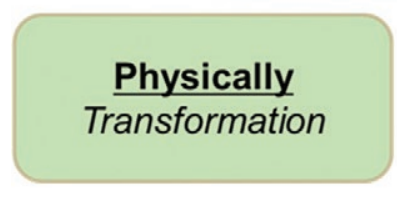
A. Arena
B. Home
C. Fanzone
D. On the go
E. "Mobile" watching

\section{Virtually}

Evolution

1. Live sports

2. News paper

3. Radio

4. Television

5. Websites

6. Social media

7. Mobile apps

8. Immersive

technologies

\section{Flexibility \\ Global Stadium}

Infographic 1: Accessing Sports Content

Moreover, all the tools and ways for content access for sports fans are typically mixed, individuvial in every single case: "For sure, it's the main channel to interact with fans, mixing online and offline" (Juan Iraola), accordingly the phenomenon of "second" (or even multiple) screens should be taken into account.

\section{"Global stadium"}

Considering the increasing accessibility of digital sports media in an internationalized sports landscape, thinking holistically, we propose a term "global stadium" to describe the aggregate of a variety of sport fandom types in nowadays complexed "sportainement" (Desbordes \& Richelieu, 2012) and fandom (Nokolai, 2020).

It has been said by Bruno Blumenschein: "Fans on the stadium" that's a concept of $1990 \ldots$ Fans now are on the global stadium and the global stadium is social networks, its online media, its platforms. So, for example, whoever is pushing hard their platform, a TV there are some official and unofficial information, that we will see a lot of changes in the way the TV pro-growth casting rights are done so far.

Big media right holders there are no longer only sports leagues in a way of you know looking at the ecosystem of sports business, but now there are media companies because they realized a decade ago the day they have enormous power in having their rights in their own hands and now knows they're they get 3.6 billion euros yearly from the TV rights. For example, take numbers they see that there are like 2 billion fans that are watching every their competition Champions League yearold, you know, whatever that you name it they have in total around 2 billion fans watching, so if you get a couple of euros from those fans you will get a lot of more money than you can get now" (Bruno Blumenschein).

What factors may affect SSCX physical and virtual relocations in nowadays Sports Marketing environment?

1. Information accessibility (24/7, from everywhere)

2. Increasing of "mobility" and "flexibility" level of fans (with advanced transportation, services industry and internet connectivity occurring all the time, fans can access content on the go, moving or being situated in almost any place): "Six years ago other fans followed 
games by TV... Another change, we can see it, for example, in Germany, there are many Korean fans, In Barcelona, we meet people from around the world, many Brazilian fans and fans from Asia. Now it's easier for a fan to follow his team moving geographically, being in a stadium on every live game, without any problem. Now a fan can reach the club very easily, and at the same time, a club can reach their fan too. I think one of the main reasons is the strategy most of the clubs are using (in football or any other kind of sports) when they open the academies in open markets such as Asia, Africa. This help a lot in reaching fans wherever they are" (Khaled Saleh)

3. New tools shift experiences to "deeper" levels (Immersion \& personalization)

4. As the result, the culture of sports spectatorship culture and fans' habits are reshaping

Table 1. The main drivers of change in SSCX physical and virtual locations

\begin{tabular}{|c|c|c|}
\hline Factor & Context & Related Technology \\
\hline \multirow{2}{*}{ Information accessibility } & $\begin{array}{c}24 / 7 \text { sports content access, } \\
\text { available from almost } \\
\text { everywhere: fans can access } \\
\text { content on the go, moving or } \\
\text { being situated in almost any } \\
\text { place }\end{array}$ & $\begin{array}{c}\text { Internet, IoT, Mobile Apps, } \\
\text { Screen-based devices }\end{array}$ \\
\cline { 1 - 3 } $\begin{array}{c}\text { Increasing of "mobility" and } \\
\text { "flexibility" level of fans }\end{array}$ & $\begin{array}{c}\text { Advanced transportation and } \\
\text { internet connectivity occurring } \\
\text { all the time }\end{array}$ \\
\hline $\begin{array}{c}\text { New tools shift experiences to } \\
\text { "deeper" levels }\end{array}$ & Immersion \& personalization & ImT (XR), Interfaces, Big data, \\
AI
\end{tabular}

\section{Conclusions}

With appearing of new forms of sports watching and content accessibility, the culture of sports consumption and fans' habits are reshaping. It includes the changes of sports consumption sports, such as physical (address) and virtual (the way of content access) locations. The shift of such locations of SSCX may be considered as the "SSCX relocations" phenomenon.

Four main factors are affecting relocations: information accessibility, increasing mobility of fans, immersion and personalization, change of fans' habits. Typically, sports content is consumed by multi-channel sources, mixing "online" and "offline", combining ways, tools, and modes of sports content access. Considering the internalization and globalization of sports fandom, it seems appropriate to describe the aggregate of fans as a "global stadium", embracing the physical and virtual locations of SSCX.

\section{Future research}

For future research, we intend to conduct an empirical study for quantitative measurements of SSCX locations, develop concept and typology to strengthen the conceptual framework of SSCX relocations. We would like to investigate the interrelation between relocations of SSCX and Sports Spectacle Digital Transformation.

\section{Acknowledgments}

We express our gratitude to Paris Sud University (France), Budapest University of Physical Education (Hungary). This work is supported by the ADI 2018 project, funded by IDEX Paris-Saclay, ANR-11- IDEX-0003-02 and program "Bourses Mobilité Île-de-France doctorants".

\section{References}

1. Behrens, A., Uhrich, S. (2020) Uniting a sport teams' global fan community: 
prototypical behavior of satellite fans enhances local fans' attitudes and perceptions of groupness, European Sport Management Quarterly, 20:5, 598-617, DOI: $10.1080 / 16184742.2019 .1643384$

2. Collins, D., Heere, B., Shapiro, S., Ridinger, L., Wear, H. (2016). The displaced fan: The importance of new media and community identification for maintaining team identity with your hometown team. European Sport Management Quarterly, 16(5), 655-674.

3. Desbordes, M., Richelieu, A. (2012). Global Sport Marketing: Contemporary Issues and Practice. Routledge, May, 208 p. January 2012.

4. Glebova, E., Desbordes, M., Geczi, G. (2020) Changes in stadia sports spectators customer experiences. Physical Education, Sport, Science (PSS), Testnevelés, Sport, Tudomány (TST).

5. Glebova E., Desfontaine, P. (2020), Sport et technologies numériques : vers de nouvelles expériences spectateur, in (Eds) Desbordes, M., Hautbois, C. (2020) Management du sports 3.0; Economica, chapter \#9, pp. $245-270$.

6. Huettermann, M., Uhrich, S., Koenigstorfer, J. (2019). Components and Outcomes of Fan Engagement in Team Sports: The Perspective of Managers and Fans. Journal of Global Sport Management 10.1080/24704067.2019.1576143.

7. Kaiser, M., Ströbel, T., Woratschek, H., Durchholz, C. (2019). How well do you know your spectators? A study on spectator segmentation based on preference analysis and willingness to pay for tickets. European Sport Management Quarterly, 19(2), 178-200. DOI: 10.1080/16184742.2018.1499790.

8. Kyle, D., Adelman, M. (1987). Spectators and Crowds in Sport History: A Critical Analysis of Allen Guttmann's „Sports Spectators”. Journal of Sport History, 14(2), 209-225. Retrieved from http://www.jstor.org/ stable/43610151

9. Nikolai, V. (2020). A Comparison of Dispersed and Local Sports Fans' Motivations for Social Media Engagement and its Effect on Fan Loyalty, Research Project Description, EASM Virtual Ph.D. Student Seminar 2020.
10. Phua Joe, J. (2010). Sports Fans and Media Use: Influence on Sports Fan Identification and Collective Self-Esteem, International Journal of Sport Communication, 2010, 3, 190-206, Human Kinetics, Inc. https://doi. org/10.1123/ijsc.3.2.190

11. Pu, H., James, J. (2017). The distant fan segment. International Journal of Sports Marketing and Sponsorship, 18(4), 418-438. doi:10.1108/IJSMS-05-2016-0022

12. Theodorakis, N.D. (2014). Customer experience in spectator sports. In book: Customer experience management: enhancing experience and value through service management, Edition: 1stChapter: 12Publisher: Kendall Hunt PublishersEditors: Jay Kandambully

13. Wann, D., Barker, P., Colajanni, L., Roel de Vries, Glantz, D. (2019). The Future of Sports Fan. Performance communication and Canva8. Retrieved from: https://www.fotball. no/globalassets/dommer/the-future-sportsfan_spilleregler_english.pdf

14. Woratschek, H., Durchholz, C., Maier, C. \& Ströbel, T. (2017). Innovations in sport management: The role of motivations and value cocreation at public viewing events. Event Management, 21(1), 1-12. DOI: $10.3727 / 15$ $2599516 X 14786350337262$.

\section{Abbreviations used:}

AR - Augmented reality CRM - Customer Relations Management CX - Customer Experiences

FC - Football club

Im $\mathrm{T}$ - Immersive technologies

IoT - Internet of Things

MR - Mixed reality

N/A - non-applicable

SSCX - Sports Spectators Customer Experiences

F/A - fully applicable

VR - Virtual reality

XR- Extended reality 